\title{
Arrangements of Employer-Labor Conflicts With Game Theory: Implementation of Islamic Ethic Value
}

\author{
Siti Najma ${ }^{1 *}$, Ramadhan Razali², Harjoni Desky ${ }^{3}$ \\ *Corresponding author
}

\begin{abstract}
Employer-labor conflicts are sometimes eternal and challenging to solve. Game theory is one of the essential ideas in settling these conflicts. Furthermore, employer-labor interactions in conflict situations are strategic. In case the employer-labor relationship is noncooperative, taking place only once, both parties are involved in a prisoner's dilemma situation. In cooperative game theory, the players work together to win the game. Organizational management needs to consider strategic behavior, built-in cooperative games, effective and efficient collaboration between workers and employers. This study examines employer-labor conflict resolution with game theory. It incorporates Islamic ethical values using qualitative research methods. Cooperative games built on employer-labor relations derive from the brotherhood principles (ukhuwah), justice ('adl), and goodness (ihsan) that maximizes cooperation and prevent conflicts.
\end{abstract}

Keywords: conflict, employer, employee, game theory, Islamic ethics

JEL Classification :C70; J01; Z12

\begin{abstract}
Abstrak. Konflik majikan-buruh terkadang abadi dan sulit dipecahkan. Teori permainan adalah salah satu gagasan penting dalam menyelesaikan konflik ini. Selain itu, interaksi pengusaha-buruh dalam situasi konflik bersifat strategis. Jika hubungan majikan-buruh tidak kooperatif, yang hanya terjadi satu kali, kedua belah pihak terjebak dalam situasi dilema narapidana. Dalam teori permainan kooperatif, para pemain bekerja sama untuk memenangkan permainan. Manajemen organisasi perlu mempertimbangkan perilaku strategis yang dibangun dalam bentuk permainan koperasi, kolaborasi yang efektif dan efisien antara pekerja dan pengusaha. Penelitian ini mengkaji resolusi konflik pengusahaburuh dengan teori permainan. Ini memasukkan nilai-nilai etika Islam dengan menggunakan metode penelitian kualitatif. Permainan koperasi yang dibangun di atas bubungan majikan-buruh bersumber dari prinsip persaudaraan (ukhuwah), keadilan ('adl), dan kebaikan (ihsan) yang memaksimalkan kerjasama dan mencegah konflik.
\end{abstract}

Kata Kunci: konflik, pengusaha, buruh, teori permainan, etika Islam

\section{How to Cite:}

Najma, S., Ramadhan., \& Desky, H. (2020). Arrangements of Employer-Labor Conflicts with Game Theory: Implementation of Islamic Ethic Value. Etikonomi: Jurnal Ekonomi, 19(2), 323 - 332. https://doi.org/10.15408/etk. v19i2.15614. 


\section{Introduction}

The focus of industrial conflict has shifted from collective confrontation to a disagreement between employers and workers (Walker \& Hamilton, 2011). This condition appears to be a lasting phenomenon in the economy, with difficulty in finding common ground. In international economic forums, labor policy reform is an influential agenda to be implemented. Half the world still faces demonstrations and workers' demands. This agenda includes developed countries like the United States (US).

The labor issue faces complex problems, especially on the increasingly widespread labor market flexibility policies (LMF). Within the neoliberal framework, workers position as economic commodities ready to be traded. Apart from guaranteeing political stability, the government often promise cheap labor costs, attracting foreign investors (Siregar, 2011). Zhou et al. (2017) identified three configurations of labor relations conflict and verified the threethree dimensions through exploratory and confirmatory factor analyses. Violations of established laws and regulations cause Rights-based conflicts. Interest-based conflict involves violations of employment terms and working conditions, which are induced by factors such as salary, welfare and working conditions. Emotion-based conflicts are caused by the employer's disrespect for employees and interpersonal conflicts between employers and employees.

Game theory is a much researched area in economics. It is a branch of applied mathematics and economics, dealing with multi-person decision making situations. There are several studies on conflict resolution between employers and employees using game theory. According to Joesoef et al. (2004), competitive strategy is dominant in managementemployees in East Java. Although both sides reached an equilibrium point, they fell into a prisoner's dilemma situation. This is because both parties stuck to their dominant strategy. Analysis of interactions among employees and employers, using game theory, show that when cooperation is established, it is likely to encounter conflicts. Yadav et al. (2015) reported that incompatibilities exist in the aims and strategies of the employers and employee due to different psychological factors. This proves inefficient or unproductive for all the involved parties. Both implicit and explicit contracts are critical in addressing authoritative behavior and facilitate cooperation on organizational safety issues.

Sigri \& Karaback (2019) manage the labor conflicts by improving the understanding of mediation dynamics from a game-theoretical perspective. Signaling game model is adapted to a hypothetical labor dispute based on the legislative regulations on the mandatory mediation system in Turkey. The paper determined mediation equilibria where both players gained positive payoffs. Jilani \& Valeed (2014) analyzed game and auction theories from the Islamic shariah perspective. The theory permits certain acts, including cheating, collusion, and unnecessary price-hiking, which directly conflict with Islam Shariah laws and practices. The auction theory also requires further refinements to come up with formats permissible in Islamic Shariah. Implementation of Islamic Shariah is expected to minimize oppression, injustice and selfish motives from trade contracts.

Assadzedeh \& Javidi (2018) used game theory to investigate the problem of eliminating a competitor from the market on an Islamic economics prospective. This article provides a new 
methodology for analyzing the reasons behind Islam's endorsement of virtues such as justice, and the condemnation of stinginess and collusion. The consequences of eliminating rivals in society have been investigated by modeling collusion in the form of a game. The results indicate that the Islamic approach achieves fair trade objectives while preventing profiteering behaviors.

From previous research, the game theory not comprehensively discussed based on Islamic perspective. The research mainly focused on the Islamic value trade contracts. This paper provides an overview of how to resolve labor conflict by implementing Islamic ethical values completely. Cooperative games derived from the brotherhood principles (ukhuwah), justice ('adl), and goodness (ihsan), place laborers as employer partners, maximizing their collaboration. The conventional conflict resolution still leaves a prolonged problem by placing the workers' as company subordinates, sabotaging effective cooperation.

The research objectives to resolve labor-employers' conflict with cooperative game theory by implementing Islamic ethical values, bringing conflicts to a total end. In case employees and employers both improve their efforts in enhancing commitment brotherhood factors, their expected individual utility payoff incurs a lower cost.

\section{Methods}

This study examines employer-labor conflict resolution with game theory. It incorporates Islamic ethical values using qualitative research methods (Moleong, 2017). Data analysis activities include reduction, data display and conclusion drawing/verification. Game theory, employer-labor relations articles and how Islam incorporates ethical values into the co-operative game theory strategy are achieved through in-depth analysis, deducing sensible conclusions and generalizations based on the obtained data sets.

\section{Result and Discussion}

A conflict is a difference in perception of interests with no alternatives. As long as there are differences, conflicts cannot be avoided and will always arise until they satisfy the aspirations of both parties (Wirawan, 2011). There are three dimensions of labor relations conflicts, including rights-based, interest-based, and emotion-based. Rights-based are caused by violations of established laws and regulations. Interest-based conflicts involve violations of employment terms and working conditions, induced by factors such as salary and welfare. Emotion-based conflicts are caused by the employer's disrespect for employees and interpersonal conflicts between the two parties (Zhou et al., 2017).

Game theory literature shows that in conflict situations, each party tries to consider the decisions to be taken by competitors. For example, when a union conducts activities demanding wage increases, it is responded to by employers with other strategic actions, such as proposing a family allowance increase. A paper published by John Nash in 1950 was a contribution to the field of Game Theory and a general understanding of strategic decisionmaking. The first part presents a non-cooperative (or competitive) solution for n-person variable sum games. This is the well-known Nash equilibrium, corresponding to a set of strategies for each agent. It provides no incentives to anybody for unilaterally changing the 
proposed strategy. The second part deals with a co-operative solution for two-person variable sum games satisfying a suitable set of axioms (1950). In 1953, Nash presented another threatening cooperative solution, when cooperation among the agents is brought about by coercion (Fragnelli \& Gambarelli, 2015).

Employer-laborer interaction in conflict situations is strategic. The parties observe, predict and count the steps of the other party. According to game theorist, a non-cooperative relationship that takes place one time (one shoot time), traps both parties in a prisoner's dilemma situation (Joesoef et al., 2004). The prisoner's dilemma is a standard example of a game analyzed in game theory, showing the reason for 2 completely rational individuals might not to co-operate, even when it appears that it is in their best interests.

Prisoner's dilemma is a two-person game where each player simultaneously chooses whether co-operate or defect. When they work together, each gets a reward R greater than the penalty $\mathrm{P}$ they both receive on failing to co-operate. There is tension between optimal rational and social individuals when the experiment gives a greater result $\mathrm{T}$ than $\mathrm{R}$ (not cooperating while others work together), and the result $S$ smaller than P (working together when others do not co-operate). In this case, non-cooperation is the dominant strategy in the game (Embrey et al., 2017).

Figure 1. The Prisoner's Dilemma

\begin{tabular}{|c|c|c|c|c|c|}
\hline C & $\mathrm{R}, \mathrm{R}$ & $\mathrm{S}, \mathrm{T}$ & C & 1,1 & $-I, 1+g$ \\
\hline D & $\mathrm{T}, \mathrm{S}$ & $P, P$ & D & $1+g,-1$ & 0,0 \\
\hline
\end{tabular}

From Figure 1, the problem with the application of economic rationality is recommending to leave co-operation commitments with other economic actors (betrayed). This is a consequence of maintaining self-interest in every economic actor. In the prisoner's game theory, economic actors' motives can clearly be illustrated. This provides an understanding that non-cooperation is more beneficial than co-operating. However, co-operating through commitments not to admit evil is unprofitable (Nurohman, 2010).

Holding salary and wage negotiations between employers, organizations and trade unions is very difficult. This is because the two parties have different interests. Workers want the highest salaries while companies want to keep them as low as possible. Negotiations can reach a dead end with no agreement (equilibrium) because of the competitive strategy applied. The prisoner's dilemma is also the result of the rules set in the game implementation, guiding the players' behavior to a non-cooperative strategy.

\section{The Relationship between Employers and Employees in Islam}

Islam offers a unique and noble concept of human relationships at the personal, family, and work levels. The basic Islamic principle shows that humans should consider one another as brothers. The principle unites all individuals in the bond of universal brotherhood and ukhuwah, as members of a single family. Every individual has the right to be equal in social status (Hoque, 2011). The economic system is based on competition and co-operation. An 
individual's economic behavior, while competitive, must be based on the desire to assist and co-operate.

Islamic teachings provide guidelines for employers to avoid the exploitation of one of the 2 parties. It emphasizes the importance of positive influence, evident from the following hadith of the Prophet Muhammad (PBUH): "Should I not tell you about what is more pious than the rank of fasting, prayer, and charity? They said: Of course! He said: Make peace with one another because the real damage to each other's relationships is haliqah. I am not talking about cutting hair, but shaving religion" (HR. Tirmidhi).

Islamic law minimizes the possibility of conflict between employers and workers (Mirza, 2016). Business people assume that sustenance is mandatory and belongs to Allah absolutely, and should be used for humanity's welfare. They consider the employee as a big family and part of their loved life. The right framework for employer-labour relations can be derived from the brotherhood principles (ukhuwah), justice ('adl), and kindness (ihsan). Moral values clean business people from basic sentiments such as exploitation, producing feelings of mutual trust and harmony. In a hadith, Rasulullah SAW said: "The workers are your brothers authorized by Allah to you. A worker should be given food, clothes, and do not be forced to do something. When necessary, the worker should be helped (Narrated by Bukhari).

In pre-Islamic societies, labor was generally meant for slaves. The slaves suffered greatly because of inadequate food, clothing and shelter. The Prophet Muhammad (PBUH) proposed a structural change rooted in the economic relations between employers and workers. Slaves that originally worked without pay were upgraded to be their master's relatives and colleagues. The Prophet expected the community to place slaves as partners and shareholders, and laid the foundation for an economy in which capital and work must join as partners, not as workers and employers. That did not abolish wages because the economic service sector could not operate without it. In the production sector, however, workers are united in the resources of their owners. They not only receive wages but also obtain other rights, such as welfare (Hasanah, 2012). Aedy (2011) shows the differences in the status of the workforce from Islamic and conventional views (See Table 1).

Table 1. Differences in Islamic and Conventional Labor

\begin{tabular}{ll}
\hline \multicolumn{1}{c}{ Islamic Labor } & \multicolumn{1}{c}{ Conventional Labor } \\
\hline Labor is a partner of the company. & $\begin{array}{l}\text { Labor is a factor of production, positioned as a subordinate to } \\
\text { the company. }\end{array}$ \\
$\begin{array}{ll}\text { Tasks performed following expertise, ability, } \\
\text { and sincerity. }\end{array}$ & $\begin{array}{l}\text { The term of sincerity is unknown because each job is a cost } \\
\text { that must be replaced with greater results. }\end{array}$ \\
$\begin{array}{ll}\text { The amount and payment must be according } \\
\text { to the agreement of the second party. }\end{array}$ & $\begin{array}{l}\text { The company determines wages and reimbursement of } \\
\text { payments unilaterally. }\end{array}$ \\
\hline
\end{tabular}

\section{Arrangements of Employers-Employees Conflict with Game Theory: Implementation of Islamic Ethics Values}

In co-operative games, players work to win the game and share the end prize. There are 2 basic questions in these games: First, with whom should a coalition win? Second, how do you share prizes when you win? 
Therefore, the players' coordinate by sharing the results outlined in 3 agreements as follows: first, a joint strategic agreement to win the game. Second, agreement on the contribution of shared resources. Third, the agreement on how to share gifts between players.

John Nash argues that non-zero-sum games are win-win, with both parties feeling happy (Raoof \& Al-Raweshidy, 2010). Analysis of the employee-employer interactions is conducted using game theory. Therefore, co-operation is an opportunity for conflict resolution. The Qur'an explains how a decision can benefit both parties, Surah Al-Anbiyaa verses 78-79: "the goat belongs to his people and the decisions given by them are witnessed. Therefore, Sulaiman has been given an understanding of the law (which is more appropriate); and to each of them we have given wisdom and knowledge and we have subdued the mountains and birds, all weaved with David, and we did it."

According to Ibn Abbas' history, group goats damaged the plants at night and the owners complained to the Prophet David. Importantly, the prophet decided that the goats be exchanged with the damaged plants. However, Prophet Sulayman (as) decided that they be handed over temporarily to those with plants. People with goats are therefore required to replace the plants. In case the new plants can be harvested, the owners may take the goats back. The Prophet Sulaiman As' gave the right decision.

The conventional labour-employers conflict resolution with co-operative game theory leaves a prolonged disagreement, because it still places the workers as a subordinate of the company, hampering effective collaboration. When employer's still view laborers only as factors of production positioned as subordinates to the company, the conflict between them never ends. Workers desire to eliminate exploitative entrepreneurs while employers want to fire workers protesting against policies from the company's elite. The emergence of power and authority gives rise to two parties, one controlling the other. In this connection, there is an association that contributes to a conflict when implemented.

In a capitalist setting, labor is considered a human-owned resource used in the production process, specifically as an input or factor of expenditure. In Islam, this would degrade humanity as God's representative on earth. Workers sell part of what they have to be compensated through wages. They should not be considered as factors of production or expenditure. By doing this, humans are submitting to other humans. Baqir al-Sadr also questioned labor as an expenditure factor since workers are human beings and not assets that may be owned.

Islam stresses on the participants' intention while game theory focuses on maximizing profits and minimizing losses by any means. Therefore, these two approaches have conflict in thought and practices. To maximize the outcome of a game, absolute cheating is permissible, while Islam is against such sinful acts. In co-operative games, collusion is allowed, while it is prohibited by the Islamic laws (Jilani \& Valeed, 2014). The economic system of Islam is based on the principles of property diversity, justice, co-operation, competition and economic ethics. These criteria create incentives for economic activity along with divine satisfaction and service to the Islamic community. (Assadzedeh \& Javidi, 2018). The labour-employers' conflict can be resolved entirely with co-operative game theory by implementing Islamic ethical values. This is based on the brotherhood principles 
(ukhuwa) justice, (adl), and goodness (ihsan), positioning laborers as partners to maximize co-operation between the parties.

Ukhuwa creates a solid and intact brotherhood and affection, ultimately making the employer-labor relations more effective and efficient. Employers' expectation from the employees in terms of production targets, attitudes, loyalties and co-operative efforts helps understand the employees' resources, desires, motivation and capacities. The employees' expectation from the employer is not only in the form of payment but also for security, the opportunity for advancement and protection. This is because they want self-expression, recognition and acceptable working conditions and environment (Yadav et al., 2015). Ukhuwa can be part of the best organizational psychology for the industry.

According to Yadev et al. (2015), optimizing the efficiency of industrial safety measures depends on strategic actions taken by the employers and employees. Therefore, an improvement in their efforts to enhance psychological factors lowers the cost of individual utility payoff. Furthermore, the individual utility payoff is expensive when they both enhance psychological factors. When the factors are enhanced by both of them, which are a costly individual decision, the other party benefits. This game can be represented in Table 2 .

Table 2. Game in Tabular Form

\begin{tabular}{llcc}
\hline & \multicolumn{3}{c}{ Employers } \\
\hline \multirow{2}{*}{ Employees } & Enhance & Sustain \\
\cline { 2 - 4 } & Sustain & Less costly, Less costly & Very costly, benefic \\
& Benefic, very costly & Costly, costly \\
\hline
\end{tabular}

Seidu (2009) stated that there is a positive relationship between good ethics in HR. There are optimal solutions to difficult situations when participants can be trusted and follow a set code of ethics. This principle is implemented in the game of the prisoner's dilemma (10 each for each player). The highest results are obtained when the players can trust each other to choose a mutually beneficial solution. Ethical human resource management may lead to profitable solutions faster than exploited learning.

Islam offers wage conflict settlement, saving the interests of both parties with the principle of wages that fulfills eligibility, justice and virtue (Hoque, 2017). A decent wage should be sufficient to meet all basic needs, including clothing, food and shelter. Rasululullah SAW teaches on payment of employees. "Whoever is a worker for us, let him find a wife (for him); in case a servant does not have one, he should find one for his servant. In case one is homeless, a place to live should be provided." Abu Bakr said: "It was reported to me that the Prophet Muhammad said: 'Who takes an attitude other than that, he is an outrageous or a thief." (HR. Abu Daud).

In addition to decency, wages in Islam must also show the principle of justice. Rasululullah is responsible for setting employee payments according to conditions, responsibilities and types of work (Syed, 2006). Justice means proportionality, and therefore, too high wage ratios are a form of injustice. The wage ratio in developed countries is between 1:25 and 1:30. Disparities that are too far trigger jealousy among 
workers, encouraging demonstrations (Sutinah, 2011). Islamic historical data shows that the minimum wage of the Prophet $(5 \mathrm{H})$ was 200 Dirhams, while the maximum was 2000 dirhams, with a ratio of 1:10. According to the development of the Medina economy at that time, the minimum payment was 300 dirhams, and the maximum was 3000 dirhams (Batubara, 2013). Currently, the company claims that it is unable to pay the minimum wage to employees, while the directors' salaries keep rising into millions of rupiahs. Middle to top directors often receives excessive wages and facilities, while workers at the operational level are limited to the minimum salary. The government should regulate this ratio since workers are also entitled to the company benefits.

Virtue (ihsan) or goodness towards others are actions taken for people beyond limits without any obligation (Qardhawi, 2002). They are comprehensive and encompassing in the world and the hereafter. They are not only limited to increasing economic (material) help, but also spiritual assistance. An example is an entrepreneur that not only thinks about personal well being but also the prosperity of all workers. Co-operative games built on employerlabor relations are derived from the principles of brotherhood (ukhuwah), justice ('adl), and goodness (ihsan) that can maximize collaboration between the parties, avoiding conflicts. The great Islamic commitment to brotherhood and justice demands that all resources be used to realize the sharia maqashid. This includes the provision of basic human needs, such as clothing, food, shelter, education and health. Workers and employers are at the same level of humanity, although in the corporate structure, there are capital owners, shareholders, and workers. Humans in society are united not to meet each other's needs, but to mutually take care of one another and responsibility for the whole welfare.

Islamic system requires a humane and fraternal (brotherhood) design while fixing the compensation. An organization should structure the compensation package for its employees in such a way that it lets them meet their basic needs and with a standard of living that is comparable with the employer, subject to the maximum of the employees' contributions with the employer. This is required by the Islamic principles of ethics, namely brotherhood, benevolence, and fairness (Ukhuwwah, Ihsan and 'adl) (Khan et al., 2010).

Al-Banna identifies the following prerequisites of a contract in Islam: equality of the contracting parties; prohibition of coercion; and conformity with general Islamic values. Al-Banna notes that in employer-employee relations, legal equality is not translated into substantive equality. Employees always remain under immense pressure to earn a living and therefore accept employers' terms and conditions. Al-Banna terms such contracts as "submission contracts", because of the employer's influence to dictate its terms in violation of the Islamic principles of justice and equality (Syed \& Ali, 2010).

Islam has defined the healthy relationship between both employee and employer by Islamic ethics include fairness in wages, honesty and justice, humility, patience, equality and unity, fairness in dealings and promise fulfillments. Muslim is obliged to implement all the Islamic ethics and teachings as an act of worshiping Allah and wish for Allah's blessings and success for all future endeavors. As a result, business would prosper to the advantage of both the employer and the employee, and the national wealth would also increase (Ali et al., 2018). 


\section{Conclusion}

Employer-labor conflicts are like eternal conflicts challenging to resolve completely. A competitive strategy is used, in which both parties stick with their dominant stands. They are, therefore trapped in the prisoner's dilemma situation. Analysis of employer-worker interactions using game theory show that co-operation provides an opportunity for conflict resolution. The players work together to win the game. Organizational management needs to consider strategic behavior in the form of co-operative games, effective and efficient collaboration between workers and employers. Unfortunately, the conventional conflict resolution leaves a prolonged conflict by positioning workers as company subordinates, hindering effective collaboration.

Islam views the employer-labor relations differently. The framework established is derived from the brotherhood principles (ukhuwah), justice ('adl), and goodness (ihsan). Islamic commitment to brotherhood and justice demands that all resources be used to realize the sharia maqashid, the fulfillment of basic human needs. Humans are united not to meet each other's needs, but to take care of one another mutually and take responsibility for the whole welfare. Employers-employee conflicts are caused by violations of established laws and regulations, violations of employment such as salary, welfare and working conditions, and interpersonal conflicts resolved in ways that prioritize mutual benefits. This study recommends resolving labor-employers' conflict with co-operative game theory by implementing Islamic ethical values, bringing conflicts to a total end. In case employees and employers both improve their efforts in enhancing commitment brotherhood factors, their expected individual utility payoff incurs a lower cost.

\section{References}

Aedy, H. (2011). Teori dan Aplikasi Ekonomi Pembangunan Perspektif Islam (Theory and Application of Islamic Perspective Development Economics). Yogyakarta : Graha Ilmu.

Ali, A. R. A. H., Noordin, B. K \& Achour, M. (2018). The Islamic Approach Of Obligations In Mutual Relations Between Employee And Employer. International Journal of Ethics and Systems, 34(3), 338-351.

Assadzedeh, A., \& Javidi, N. (2018). Ethical Principles in Business, Application of Game Theory in Islamic Economics. International Journal of Management And Applied Science, 4(3), 16-19.

Batubara, I. (2013). Perspektif Hukum Islam Tentang Dinamika Hubungan Industrial Di Indonesia (Islamic Law Perspectives on the Dynamics of Industrial Relations in Indonesia). Miqot, 32(2), 347-373.

Embrey, M., Frechette, G.R., \& Yuksel, S. (2017). Cooperation in the Finitely

Repeated Prisoner's Dilemma. Quarterly Journal of Economics, 133(1), 509-55.

Hasanah, U. (2012). Hak-hak Buruh dalam Perspektif Hukum Islam (Labor Rights in Islamic Law Perspective). Law Review, 12(1), 55-69.

Hoque, N. (2011). Industrial Relations - An Islamic Approach. IIUC STUDIES, 8, 39-58. Hoque, K.A. (2017). Wage Principles in Islamic Law. International Journal of Ethics in Social Science, 5(1), 126-134. 
Jilani, A., \& Valeed, A. A. (2014). Game Theory and Auctions from Islamic Viewpoint. Retrieved from: https://papers.ssrn.com/sol3/papers.cfm?abstract_id=2481524.

Joesoef, J. R., Prasetio, T., \& Sulistiyanti. (2004). Analisis Konflik Majikan-Buruh dalam Kerangka Game Theory: Penerapan Analytic Hierarchy Process (Analysis of EmployerLabor Conflict in Game Theory Framework: Application of Analytic Hierarchy Process). Jurnal EKOBIS, 5 (1), 1-18.

Khan, B., Farooq, A. \& Hussain, Z. (2010), Human Resource Management: An Islamic Perspective, Asia-Pacific Journal of Business Administration, 2(1), 17 - 34.

Mirza, M. O. N. (2016). Employer-Employee Relationship in Islam: A Normative View from the Perspective of Orthodox Islamic Scholars. International Journal of Business and Management, 11(4), 59-70.

Moleong, L. J. (2017). Metodologi Penelitian Kualitatif(Qualitative Research Methodology.). Bandung: Rosda Karya.

Nurohman, D. (2010). Konsep Self-Interest dan Maslahah Dalam Rasionalitas Ekonomi Islam (The Concept of Self-Interest and Maslahah in Islamic Economic Rationality). Jurnal Islamica, 5(1), 100-115.

Qardhawi, Y. 2002. Teologi Kemiskinan (Poverty Theology). Yogyakarta: Mitra Pustaka.

Raoof, O., \& Al-Raweshidy, H. (2010). Theory of Games: An Introduction. Rijeka: Sciyo.

Seidu, A. M. (2009). Islamic Concept of Employer-Employee Relationships: An Instrument for Managing Human Resources and Certain Operational Risk Exposures. Legon Journal of Sociology, 3(2), 45 - 69.

Sigri, U \& Karabacak, H. (2019). Conflict Resolution Role of Mediation in Labor Disputes in Turkey: Evidence from a Signaling Game. International Journal of Conflict Management, 30(3), 395-415. https://doi.org/10.1108/IJCMA-01-2019-0013.

Siregar, A. E. (2011). Buruh dan Politik (Labor and Politics). Jurnal Sosial Demokrasi, 10 (4), 4-15.

Sutinah. (2011). Konflik Industrial: Suatu Kajian Kritis Terhadap Konflik Industrial (Industrial Conflict: A Critical Study of Industrial Conflict). Media Dialektika, 6(2), 1-14.

Syed, K. A. (2006). Wage Differential in an Islamic Frame Work. Thoughts on Economics, 16(1), 47- 53 .

Syed, J. \& Ali, A. J. (2010). Principles of Employment Relations in Islam: A Normative View. Employee Relations, 32(5), 2010 454-469.

Walker, B., \& Hamilton, R.T. (2011). Employee - Employer Grievances. International Journal of Management Reviews, 13, 40 - 58

Wirawan. (2011). Konflik dan Manajemen Konflik: Teori, Aplikasi, dan Penelitian (Conflict and Conflict Management: Theory, Application, and Research). Jakarta: Salemba Empat.

Yadav, R., Pareek, S., \& Singh, S. (2015). Game Theory in Organizational Psychology. International Journal of Advances in Science Engineering and Technology, Special Issue-1, 16 - 120.

Zhou, L., Xi, M., Zhang, K., \& Zhao, S. (2017). Labor Relations Conflflict in the Workplace: Scale Development, Consequences and Solutions. Conflict and its Resolution in the Changing World of Work: A Conference and Special Issue Honoring David B. Lipsky. Cornell University ILR School. 